\title{
PROTECTION OF "NEIGHBORING RIGHTS"
}

\author{
George H. C. Bodenhausen*
}

Although the systems of copyright protection in the countries belonging to the Berne Convention for the Protection of Literary and Artistic Works on the one hand and in the United States and several other countries of the Western Hemisphere on the other, may differ in various respects, they also have important points of similarity. One of these points of likeness is that, in principle, only a literary or artistic work can be protected by copyright. Generally speaking, such protection is not extended-or at any rate not on the same footing-to materials which are not far removed, such as: news (not the form thereof, which is eligible for copyright protection, but the content), ideas (again apart from their concrete form), the performance of literary or artistic works by artists, the recording or broadcasting thereof, etc.

The line of demarcation between what is and what is not capable of protection in this way will of necessity always be dependent on the one hand on the consideration that parasitic imitation or exploitation of another's intellectual performance is socially undesirable, and on the other hand on the recognition that as much liberty as possible should be left to industry and trade. It is undeniable, however, that tradition also plays a certain part in this matter: after all, the origin of copyright is the desire to protect literary works against plagiarism ${ }^{2}$ and this origin makes itself felt with great persistency and constitutes an obstacle to the early incorporation of new technical developments into copyright legislation.

However this may be, there is a serious question today whether this situation is satisfactory, and particularly whether, if not the copyright itself, then in any case "neighboring rights" should concern themselves with the protection of the materials referred to above. It is my intention to consider some aspects of this problem in the following pages. I shall confine myself to the possibilities of protecting performers, recorders, and broadcasters, because these possibilities in particular have attracted much attention of late and have led to the publication of a voluminous literature. ${ }^{3}$

* LL.M. x927, Leiden; Professor of Law, Utrecht University. Counselor at Law, The Haguc. Mcmber of the Permanent Committee of the Berne Convention for the Protection of Literary and Artistic Works and of Its Executive Subcommittee. Member and Reporter-General of the Committec of Experts concerning "neighboring rights," Rome, 195I; Vice President of the Association Littéraire ct Artistique Internationale (Paris). Chairman of the Advisory Committee on Copyright to the Netherlands Ministry of Justice; Chairman of the Netherlands delegations at the Brussels Conference (1948) on Revision of the Berne Convention and at the Geneva Conference (r952) on the Universal Copyright Convention. Author of articles and books on copyright and industrial property.

${ }^{2}$ Cf. inter alia, A. Bogsch in Droit d'Auteur 1952, p. 30.

${ }^{2}$ Herbert a. Howeli, The Copyright Law i (3d ed. 1952); Copinger on the Law of Copymtoitt I (8th ed., Skone James, I948); P. Olagnier, Le Droit d'Auteur, I, p. 77.

${ }^{3}$ E.g., the following recent literature, nearly all referring to former publications: G. STraschnov, LE 
It is well known in Europe that the questions to be examined here have been raised also in the United States and in other countries of the Western Hemisphere and have led in some countries to legislation or to important judicial pronouncements. ${ }^{4}$ Nevertheless, in the following pages $I$ shall deliberately refrain from any discussion of the status of these problems in the Western Hemisphere. I prefer to confine myself to a brief presentation of data with reference to views and results in some European countries belonging to the Berne Convention, leaving it to the expert reader to draw a comparison with the situation on the American continent. In this connection, I would express the hope that up-to-date information concerning this latter situation will shortly be furnished in an authoritative European periodical, so that the comparative study can be made in both directions.

At the latest Revision of the Berne Convention in Brussels in 1948, in which thirty-five countries participated." the following "wishes," among others, were adopted: ${ }^{6}$

VI The Conference expresses the wish that the Governments of the countries of the Union should study the means of ensuring the protection of the manufacturers of instruments for the mechanical reproduction of musical works, without detracting from the rights of the authors. ${ }^{7}$

VII The Conference expresses the wish that the Governments of the countries of the Union should study the means of ensuring the protection of the transmissions made by the radio broadcasting institutions, for the purpose of preventing any unauthorized utilization thereof, without detracting from the rights of the authors. ${ }^{8}$

VIII Considering that the interpretations of the performers have an artistic character, the Conference expresses the wish that studies should be actively pursued with reference to the neighboring rights of copyright and particularly the protection of the performers. ${ }^{9}$

DROIT D'AUTEUR ET LES DROITS CONNEXES EN RADIODIFFUSION (1948), and, by the same author, NouvEAUX ASPECTS DU DROIT D'AUTEUR ET DES DROITS CONNEXES EN RADIODIFFUSION (1950) [hereinafter referred to as STRAschnov I and II respectively]; M. Saporta, Les droits dits "connexes" aut droit d'auteur, RevuE Internationale DE dRoIt comparé 42 (I952); W. MAK, Rights AfFecting the Manufacture and USE of Gramophone Records (The Hague, I952); Report of the Copyright Commitree, Nos. 76-93 AND I15-203 (London, I952); L. Leuzinger, Stellungnahme des Interpreten zum römischen Konventionsentwurf betreffend die Rechte der ausübenden Künstler, der Schallplattenproduzenten und der Rundfunk-

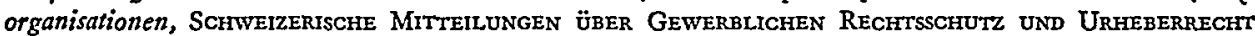
I79 (1952); Th. Moll, Die Rechte der ausiibenden Kïnstler, der Hersteller von Phonogrammen und der

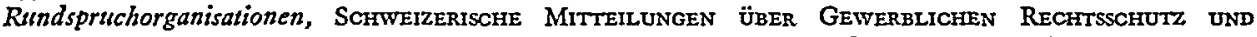
URHEBERRECHT I5 (I953); H. Hubmann, Der Schutz der Rundfunksendung gegen unbefugte Verwertung, GEWERBLICHER RECHTSSCHUTZ UND URHEBERRECHT [hereinafter referred to as GRUR] 3I6 (I953); and several articles in more specialized periodicals relating to broadcasting and recording, e.g., A. Baum, Le projet de Rome concernant la protection des artistes executants, des fabricants de phonogrammes et des organismes de radiodiffusion, IV BULLETIN DE DOCUMENTATION ET D'INFORMATION DE L'UNION EUROPÉENNE de Radiodiffusion 5 II (1953) (also, in German, in GRUR, Auslands UNd INTERnationaler Teil r97 (1953)).

'Cf. inter alia, W. Strauss, La protection des droits de l'artiste executant aux Etats-Unis d'Amérique, Droit d'Auteur I950, p. II0; also I STRAschnov, op. cit. supra note 3, at 202; II id. at 3I; Saporta, stupra note 3 , at 52 et seq.

'Documents de la Conférence réunie à Bruxelles [hereinafter Doc. Brux.] 54 (I95I).

Id. at 587 .

${ }^{7}$ Accepted with eight abstentions, no dissenting votes, Doc. Brux. 428 .

${ }^{8}$ Accepted with six absentions, no dissenting votes, Doc. BRux. 428.

- Accepted with two abstentions, no dissenting votes, Doc. Brux. 428. 
These "wishes" were not superfluous. Protection as referred to therein already exists by statute in some countries, and there and elsewhere the courts also derive protective consequences from, for instance, general statutory provisions against torts or unfair competition or from principles of common law or equity; however, this does not alter the fact that it was and is widely felt that these questions call for more unity of ideas and, in any case, cannot be left permanently to very general legal provisions and/or development via the courts. The reasons for this lastmentioned consideration are that the delimitation of the protection to be awarded, in view of the public interest and the interplay of the private interests concerned, is an extremely delicate task and one which cannot satisfactorily be performed by the courts. Consequently, there was and is a widespread feeling in various countries ${ }^{10}$ that this situation constitutes a challenge to the legislator and even to the international legislator (viz., by the conclusion of a multilateral Convention), in view of the fact that the performances to which protection may be given in this case naturally extend beyond the national frontiers and the protection should preferably not cease to operate thereby or should not be arranged with too much diversity.

At the Revision of the Berne Convention in Brussels in 1948, a resolution was also passed $^{11}$ establishing a Permanent Committee, consisting of representatives of twelve countries retiring by rotation, which received instructions to assist the Office of the Convention in the fulfillment of its task. This Permanent Committee and an Executive Subcommittee formed from it have on several occasions, with the support of the International Labor Organization in Geneva, concerned themselves with the implementation of the aforesaid "wishes."12 As a result in November $195 \mathrm{I}$, in Rome, a committee of experts drew up a Draft Convention, ${ }^{13}$ about which a number of governments are now being consulted. If the Draft meets with a favorable reception in principle, further steps will be taken, first by a new committee of experts and finally by a Diplomatic Conference, for the preparation of a Convention. ${ }^{14}$

A few details of this work will be dealt with in the following pages. I should like, however, to clear the ground for a discussion of the subject by first of all devoting some remarks to two questions, viz.:

I. What arguments can be adduced for and against legal protection of neighboring rights for performers, recorders, and broadcasters, and what is the relation of such protection to copyright proper?

\footnotetext{
${ }^{10}$ When I speak here of widespread feelings this is based on my experience in national and international committees; what follows in the text, however, reflects only my personal opinion.

${ }^{11}$ Doc. Brux. 585.

${ }^{12}$ Cf. resolution No. 2 of the Permanent Committce in Neuchâtel, Sept. 28-30, 1949, Droit d'Auteur 1949, p. 132; resolution No. 2 of this Committee in Lisbon, Oct. I6-2r, r950, Droit d'Auteur 1950, p. 13I; resolution No. 2 of the Executive Subcommittee in Paris, March 9-10, 1951, Droit d'Auteur 1951, p. 36; resolution No. 2 of this Subcommittee in Stresa, May 30-31, 1951, Droit d'Auteur 1951, p. 70; resolution No. 2 of the Permanent Committee in Paris, Oct. 25-27, 195I, Droit d'Auteur r95I, p. 125.

${ }^{13}$ Droit d'Auteur 195I, p. 140.

14 Cf. resolution No. 6 of the Permanent Committee in Neuchâtel, July 1-3, 1952, Droit d'Autcur 1952, p. I03; resolution No. 2 of the Executive Subcommittee in Berne, June 23-24, 1953, Droit d'Auteur I943, p. 82 .
} 
2. What is the situation regarding these problems in various countries, particularly those which have up-to-date legislation on the subject or in which such legislation is in the course of preparation?

Concerning the first question, so far as the relationship of any neighboring rights, which may be granted as above, to the traditional copyright is involved, the line of demarcation between literary and artistic works, which can be protected by copyright, and the performance, recording or broadcasting of such works-whether protected by copyright or not-seems to be fundamental, but is not so in reality. In this case adaptations-for instance, translations, transpositions of musical works-are also protected by copyright, but what is the fundamental difference between the adaptation-for instance, in the form of a literal translation-and the faithful reproduction on a record? Or what is the fundamental difference between an artistic performance and a simple musical transposition?

We must free ourselves to some extent from the traditional conceptions of copyright. Up to a few decades ago, printing and similar processes were practically the only methods by which literary and artistic works or adaptations thereof could be recorded on a large scale and distributed widely in space and time. Since then technical progress has made this possible for the concrete performance of works: the question may be asked whether this must not lead, to a certain extent, to revision or supplementation of the existing theoretical conceptions.

In any case, it should be noted that the line of demarcation between what is and what is not regarded as eligible for copyright as literary or artistic work is drawn differently in different countries. Thus, as will be seen below, in some countries the performance of a work, provided it is recorded, as well as the recording itself, are regarded as works protected by copyright. It may be disputed whether this is theoretically correct; the phenomenon, however, shows in any case that in practice the frontier of the territory to be protected by copyright is flexible.

A second remark concerning the relationship between any neighboring rights for performers, recorders, and broadcasters, which may be recognized by statute, and copyright is that it can never prejudice the rights of the author to the original literary or artistic work. The author retains the right-in so far and as long as his copyright extends-to forbid or to impose conditions with reference to any use of his work, including its use in any particular special performance or in or pursuant to any concrete recording, etc. Consequently, any neighboring rights to be granted relating to performance, recording or broadcasting can only become effective if and in so far as the author imposes no obstacle thereto. Moreover, these rights will of course only cover a more limited field, viz., only the use of the concrete performance, recording or broadcast.

This does not alter the fact that the interests of the author of a literary or artistic work will be concerned if rights to the concrete performance, recording or broadcast thereof are granted to third parties. It is quite conceivable that the author will welcome distribution of a certain concrete performance, etc. of his work, which 
is likely to bring him profit, whereas the performer will oppose this distribution, because he prefers to be re-engaged for a performance rather than to have the mechanical reproduction of his original performance exploited by third parties. Moreover, even if the performer does agree to such exploitation, it is possible that the remuneration which he demands therefore will unfavorably influence that which the author can claim.

The delicate relationship between the interest of the author and the interest of candidates for the grant of neighboring rights may in itself be an argument against such a grant. In any case, it leads to a further brief consideration of the arguments which can be adduced for and against legal protection of these rights.

Another circumstance which certainly militates against the grant of such protection is that it is extremely difficult to attain effectively. The interests concerned are interrelated, because the one performance to be protected is likewise the "raw material" for another: the artist's performance is recorded and the record is broadcast; the same relations exist in the case of films (which, however, are already protected by copyright practically everywhere) ${ }^{15}$ and television. Consequently, protection of the performers will almost necessarily be directed against the recorders, film makers, and broadcasters; that of the recorders against the broadcasters, etc. This makes it a very difficult and delicate matter to reconcile all the interests concerned.

Another weighty objection to the granting of neighboring rights as discussed here is that such a grant threatens to impose a heavy burden on the ultimate consumer of all the performances, i.e., the public. Let us assume that protection of performers, recorders, and broadcasters would also have to cover them against exploitation of their performances by third parties, who ultimately communicate these performances to the public (this question will be discussed later). It then is by no means inconceivable that, for instance, the proprietor of the restaurant or cinema who communicates to his public a relay of a foreign radio or television transmission whereby use is made of previous recordings (gramophone records or films) will be assailed with claims of:

(x) the authors of works adapted for the transmission (e.g., music), (2) the authors of the work itself (film or radio play) which is transmitted, (3) the performers, (4) the recorders, (5) the original transmitter, and (6) the relayer.

This certainly is not an attractive prospect.

But the reverse of the medal should also be viewed, by examining the arguments for protection of performers, recorders, and broadcasters.

Some questions appear to present little difficulty in this connection, for example, those where protection is certainly necessary-although perhaps, considering the existing general provisions or principles, these do not necessarily require special regulation. These include protection:

of the broadcasts against unauthorized rebroadcasting;

${ }^{16}$ Cinematographic Works, H. L. Pinner (ED.), I Wordd Copyrigur 705-776 (1953). 
of the records against unauthorized copying thereof;

of the performers against clandestine recording or broadcasting of their performance, for which they have not contracted.

Such protection can be regarded as arising from general principles of fairness, so that recognition by statute can offer only greater security. However we soon get into difficulties with the elaboration of these principles, for instance, if we ask whether broadcasts should also be protected against unauthorized recording, or, in particular, television protected against kinescope recording. Further problems arise if, as regards broadcasts and records, the question is raised to what extent recording or copying thereof for private use should also be opposed or should be subjected to certain conditions. As a matter of fact, these are matters which have not yet been settled satisfactorily in most countries even as regards the copyright.

The real difficulties arise, however, if we ask to what extent the three groups of performances here referred to-i.e., those of performers, recorders, and broadcasters -also deserve protection against commercial exploitation by third parties, viz., by communication thereof to the public by means of the playing of records, the provision of facilities for listening to sound radio, or the showing of television programs in public places, such as restaurants, dance halls, cinemas, etc.

The interests do not coincide here in all cases.

In many countries, it has been customary for years that records and sound broadcasts can be utilized by third parties for commercial exploitation in the above sense, without the recorder or broadcaster being able to exercise any influence thereon (in some countries the authors are entitled to exert such influence, in other countries they are not). It can be said that the interests have adjusted themselves to this situation and that it has not given rise to any special difficulties. On the other hand, the experience gained with the opposite kind of system-for instance, in the United Kingdom, where copyright attaches to records, so that they are protected against commercial exploitation by third parties-has not been altogether favorable. ${ }^{16}$

The situation is different, however, with regard to television, since in this case the commercial exploitation of the television transmission by third parties-for instance, in restaurants and even in cinemas-can offer so much competition to the televised event itself-no matter whether this is a cultural manifestation, such as an opera, or a sporting event, or a festivity, with a charge for admission-that permission for the television will be refused, if there is no possibility to keep a check on its commercial exploitation. In other words, if television is to perform its function in the best possible way, control of its commercial exploitation by third parties is imperative, and it would seem to be extremely doubtful whether this control can be attained otherwise than by expressly granting legal powers. ${ }^{17}$

\footnotetext{
${ }^{10}$ Report of the Copyright Committee, CMd. No. 8662, at Nos. 140-I57, 18x-185, 194-200 (London, 1952).

${ }^{17} \mathrm{Cf}$. II StRaschnov, op. cit. supra note 3 , at 35 , concerning the issue of a warning before the transmission that reception in public is prohibited, or the invocation of a right of privacy for those whose "portrait" is televised.
} 
A still more delicate question is whether performances of dramatic and musical performers-orchestras, conductors, soloists, stage and film actors, elocutionists, and ballet dancers-should be protected against unauthorized exploitation by third parties, who communicate fixations or broadcasts of such performances to the public. The necessity for such protection has been put forward for years by the artists and their organizations; they emphasize the intolerable circumstance that the exploitation (the mechanical distribution) of their own performances competes against themselves (this applies less, of course, to films than to records and broadcasts).

Data with reference to the importance of this question are to be found, inter alia, in a report submitted in 195I to the International Labor Organization in Geneva by its Consultative Committee of Employees and Intellectual Workers. ${ }^{18}$ The first chapter of this report commences with the sentence:

The livelihood and the working conditions of artistic performers of all categories seem to be very seriously endangered as a result of the increase and the widespread utilization of recording methods and techniques and of sound and television broadcasts of their performances and interpretations.

With reference to this question the report gives further particulars which show that, for instance, in the spring of 1948 the unemployment index for dramatic and musical performers in the fifteen largest cities of the United States was between 27.3 and r5.6 per cent, as compared with a general unemployment percentage of 3.6 to 2.9 per cent, and that in France the unemployment figure for theatrical workers was 70 per cent in 1949, while in Northern Ireland and Western Germany (in I95I) this percentage was 66 and 25 per cent, respectively.

Even if such figures cannot be considered representative for all countries and all periods, they certainly constitute a social and economic problem-and a problem of justice!-which it would seem impossible to put aside without serious consideration.

However, we are concerned here with more or less explosive material, for it should be realized that if a right were to be granted to the dramatic and musical performers on the lines of copyright, which would enable them to oppose unauthorized mechanical distribution of their performances, they would make use of this right otherwise than the authors usually do. As a rule, an author is anxious only that his work be performed; his sole demand is that he should be awarded a remuneration therefor. The dramatic and musical performers, on the contrary, will wish to oppose all kinds of mechanical distribution of their performances; they will not-at least not always-be satisfied with remuneration, because they prefer an engagement for another performance.

Since, moreover, the possibility has to be taken into account that dramatic and musical performers could cede to their organizations, to performing-rights societies or, for instance, to the gramophone industry, the rights to be awarded to them, it is clear that great power could be wielded with these rights. Hence the question has

${ }^{18}$ Commission Consultative des employes et des travailleurs intellectuels, Report III (Geneva, I95I). 
also arisen whether it would not be better to restrict any protection to be granted merely to a right to remuneration, so that no exclusive right would be awarded which could entirely prevent the commercial exploitation of the performance.

This brief review of the opposing interests and arguments must end here because, as noted above, I wish to preface the discussion of the present international situation with a second preliminary orientation, viz., concerning statutes which already wholly or partly regulate the relations referred to.

A review of some existing statutes can best be given in reverse chronological order, because it is to be assumed that the most recent laws have profited by the experience with the older ones.

As far as I know, the most up-to-date legislation (in the sphere of the Berne Convention) which contains detailed provisions with reference to this subject is the Italian law of 22 April 1941 for the protection of copyright and other rights connected with the exercise thereof..$^{19}$ The relevant provisions-Articles 72 to 85 -are too lengthy to be discussed here in detail, ${ }^{20}$ but they can be summarized as follows:

(a) The manufacturer of records or similar materials has (Art. $7^{2}$ ) the exclusive right to reproduce them and to place these reproductions on the market; furthermore, when his records are used with the intention of making a profit by broadcasters and cinemas, or at public events (except for education or state propaganda), he has: (r) (Art. 73) the right to a remuneration (to be settled in accordance with Art. 23, Regulations); and (2) (Art. 74) the right to forbid such a use under circumstances where serious and unwarranted damage would be done to his industrial interests. The duration of these rights (Art. 75) is thirty years after the deposit of a copy of the record, but in no event longer than forty years after its original manufacture. The title of the work, the names of the author and of the performers, and the date of manufacture must be indicated on the record (Art. 76 juncto Art. 62).

(b) The broadcasting institution is granted (Art. 79) the exclusive right for its productions:

(I) to relay by wire or to rebroadcast;

(2) to record the transmission for the purpose of making profit; and

(3) to use these records for fresh transmissions or for fresh recording.

(c) A definition of dramatic and musical performers is given (Art. 82) which excludes from the protection absolutely unimportant performances. On the other hand (Art. 83), the right to have the artist's name mentioned is accorded to the most important performances. The performers have furthermore: (I) (Art. 80) the right to a fair remuneration (to be settled in accordance with Art. 25 of the Regulations) from those who (otherwise than by virtue of a direct contract with the performer, who is thereby remunerated) transmit their performance by radio or by

\footnotetext{
${ }^{10}$ Droit d'Auteur 1941, p. 97, with appurtenant Regulations in Droit d'Auteur 1953, p. 25. Knowing no Italian, I have had to rely on the French translations of the law and the regulations.

${ }^{20}$ As a matter of fact, other so-called neighboring rights have been dealt with in this law, viz., those referring to designs for theatrical scenery, photographs, letters, portraits, engineering projects, and titles.
} 
wire or record it on a record or film, and from those who subsequently, by the same means, transmit or reproduce a performance which has already been broadcast or recorded (the simple communication to the public of the broadcast or recording does not appear to be included thereunder, which is in contrast with the rights of the manufacturer of records); no remuneration is payable, however, by a radio institution on account of recording for its own broadcasting; and (2) (Art. 8r) the right to forbid a broadcast or recording of their performance which may be prejudicial to their honor or reputation. The right of the performers to remuneration lasts for twenty years after their performance.

The Austrian law of 9 April $1936^{21}$ regarding the copyright of literary and artistic works as well as allied rights, is also a relatively modern one, which expressly regulates the protections discussed in this article. The provisions which are important in this connection are Articles 66-72 and 76.22 The gist of them is as follows:

(a) The performers are awarded the exclusive right (Art. 66) to record their performances (also in the case of broadcasting) on any recording apparatus for image or sound and to the reproduction and marketing thereof. In the case of performances by several performers under a conductor, however, this right is restricted to the conductor and the soloists. Recordings made contrary to this exclusive right may not be broadcast or reproduced in public (thus, with recordings the making of which did not constitute an infringement of the exclusive right, these acts are allowed). Similar rights also accrue to the organizer of the performance. The rights of the performers last for thirty years after their performance. Moreover, they have (Art. 68) the right to decide whether their names will be mentioned when their performances are recorded. Some restrictions are given (Art. 69) for commentaries, films, and recordings for private use.

Broadcasting is (Art. 70 ) subject to the exclusive rights of the performers in the same way as recordings; broadcasting, however, of recordings whose manufacture was authorized can be made freely.

Finally (Art. $7 x$ ), similar regulations are given for the showing in public of manifestations of performers; this, too, is subject to their consent, unless it involves recordings whose manufacture was duly authorized or radio broadcasts made with proper authorization.

(b) The manufacturers of gramophone records (Art. 76) are protected against reproduction of their records and the marketing of such reproductions; reproductions manufactured in contravention of this protection may not be used for broadcasting or communication to the public (thus reproductions the manufacture of which did not constitute an infringement of the exclusive right may be so used). Reproduction

${ }^{21}$ Droit d'Auteur 1936, pp. 6r, 74, 85; see also amendments in Droit d'Auteur 1949, p. 109, Droit

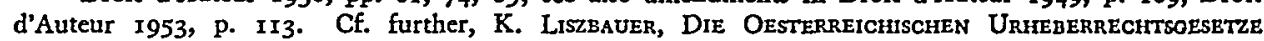
(1936).

${ }_{22}$ In this law, too, other rights in this connection are likewise established, viz.: to photographs, letters, portraits, news reports, and titles. 
for private use is not subject to any restriction. The right of the gramophone manufacturer lasts for thirty years after the manufacture, or if publication has taken place, for thirty years after the publication.

(c) The Austrian law grants no protection to the broadcast as such.

Another country that is worthy of attention is Denmark, where a Copyright Law of 26 April I933 $^{23}$ and a Broadcasting Law of 2I March r930, amended 30 March $1946,{ }^{24}$ are in force.

The protection of performers is not covered in this legislation. ${ }^{25}$ According to the courts, ${ }^{26}$ however, a real copyright exists with reference to the gramophone record as such-just as, for instance, in the United Kingdom; this copyright is entirely similar to other copyright and thus protects the gramophone record as such against unauthorized broadcasting and public petformance.

The law relating to radio broadcasting gives such broadcasting a very general protection, since it provides that any direct or indirect commercial exploitation of radio broadcasts without the previous consent of the broadcasting institution (a state body in Denmark) is prohibited.

Among the other countries which call for discussion in this connection, mention may be made of Switzerland, where the Federal Law of 7 December $x 922^{27}$ regarding copyright of literary and artistic works is in force. This law provides in Article 4 that if a literary or artistic work is adapted for records by the personal collaboration of performers, this constitutes an adaptation, which is protected by copyright. A copyright for the performer is thereby recognized, but only in so far as his performance is recorded on a record. The Swiss Federal Court has decided with reference thereto: $:^{28}$ (I) that tacit cession of this right by the performer to the manufacturer can be assumed, and (2) that communication to the public of lawfully manufactured records is allowed, but not radio broadcasting thereof, without previous consent.

The protection given here, based on one provision of the law, is of course very incomplete. So far Swiss law has granted no protection to the radio broadcast as such. ${ }^{29}$

In the United Kingdom there are also legal provisions which provide some protection here. This protection comprises:

(a) For gramophone records, there is full copyright in accordance with Section Ig of the Copyright Act, rgir: ${ }^{30}$

${ }^{23}$ Droit d'Auteur 1933, p. 85. Knowing no Danish, I have had to rely on the French translation of this law.

${ }^{24}$ French translation in Bulletin DE Documentation et d'information générales de Ia RadioDIFFUSION FRANCAISE (No. 7) II (I946).

${ }^{25}$ Torben Lund, in Pinner (ED.), I World Copyright 583 (I953).

${ }^{28}$ Case reported by I Straschnov, op. cit. supra note 3, at 128, and by Lund, supra note 25, at 583 .

${ }^{27}$ Droit d'Auteur 1923, p. 6r.

${ }^{38}$ Federal Tribunal, July 7, 1936, BundescerichtLiche ENtscheidungen, 62-II, 243, 250 under 5, 25 I under 6.

${ }^{20} \mathrm{~J}$. Buser in PinNer (Ed.), I World Copyrught $6 \mathrm{r}_{4}$ under (7) (1953).

${ }^{30}$ Copinger on the Law of Copyright 240 (8th ed., Skone James, 1948). 
Copyright shall subsist in records, perforated rolls and other contrivances by means of which sounds may be mechanically reproduced, in like manner as if such contrivances were musical works. ...

(b) For performers, there is protection by the Dramatic and Musical Performers' Protection Act, x925, which declares that any person knowingly making any record of a dramatic or musical performance without the consent in writing of the performer, and also the sale, hiring, distribution or performance of any record so made, shall be punishable. ${ }^{31}$

(c) So far no protection has been provided in the United Kingdom for broadcasting as such.

Almost as important, however, as the existing legal provisions in the United Kingdom are the proposals for amendment which are to be found in the remarkable Report of the Copyright Committee, I952. ${ }^{32}$ In Parts VI and VII, Nos. 76-203, this report deals in great detail with the questions which have been briefly discussed above and casts a clear light on the interests concerned. The recommendations based thereon (see Summary of Report, pp. II6 ff.), Nos. I9-4I, amount briefly to the following:

(a) The copyright on records should be maintained-though restricted in duration to twenty-five years after first issue to the public-and should also explicitly cover the broadcasting of a record and the public performance thereof.

(b) No protection should be given to the personal interpretation of music, etc. by artists, but the protection provided by the Dramatic and Musical Performers' Protection Act, I925, should be maintained and should possibly be extended to prohibit clandestine broadcasting.

(c) A broadcasting station should have the right to prevent the copying of its programs either by rebroadcasting or by the making of records for sale and subsequent performance, and a new right in the nature of a performing right should be given to a broadcasting station in its television programs but not in sound programs.

All the above recommendations are made with the important reservation that the exercise of rights by collecting societies of a monopolistic or quasi-monopolistic character (or a broadcasting station in respect of licenses for public performance) should be subject to control by a neutral body.

The last country that I should like to discuss in this connection is Germany (viz., the situation in the Federal Republic, since no sufficiently reliable data are available with reference to the situation in the Democratic Republic).

The laws which are applicable there are those of Ig June rgor regarding copyright in literary and musical works, and of 9 January Ig07 concerning copyright in plastic arts and photographs (both laws have since been amended). ${ }^{33}$ As a result of this legislation, the situation concerning the protection of dramatic and musical artists and gramophone record manufacturers is practically the same as in Switzer-

\footnotetext{
${ }^{31}$ Id. at 190.

${ }^{32}$ Card. No. 8662 , at 30-74.

${ }^{33}$ Cf. Voigtzänder-Elster-KLeine, Die Gesetze betreffend das URheberrecht (4th ed. 1952).
} 
land. The German law, however, is clearer than the Swiss, for in Article 2, paragraph 2 , it expressly provides that:

If a literary or musical work is transferred by personal performance to instruments which serve for the mechanical reproduction for the ear, the instrument manufactured in this way shall be on a par with an adaptation of the work. . . . The performer ... shall be regarded as adapter.

Consequently, in Germany the performer who has his performance recorded on a record thereby produces an adaptation which in itself is protected by copyright. Legal writers ${ }^{34}$ assume that this right can be regarded as tacitly transferred to the manufacturer of the record, but usually there is an express transfer.

In virtue of a special provision of the German Law (Art. $22^{a}$ ), public performance of a lawfully manufactured record is free; according to the courts, ${ }^{35}$ however, this does not include broadcasting of the record, which is thus subject to the consent of the party owning the copyright of the record.

A more far-reaching protection of the performers-for instance, if their performance has not been recorded on a record-or of the gramophone record manufacturer as such can possibly be claimed according to German law on the ground of general legal provisions; there is a great deal of literature ${ }^{36}$ on the subject, but comparatively few judicial rulings, ${ }^{37}$ so that these possibilities appear uncertain.

A detailed consideration of the protection of radio broadcasts as such, recently published by $\mathrm{H}$. Hubmann, ${ }^{38}$ mentions literature and court decisions on this question. Hubmann comes to the conclusion that in Germany a restricted administrative and criminal law protection for radio broadcasts exists (curiously enough, with variations in the different zones of occupation), but that this protection is inadequate so that the question whether a civil law protection can also be deduced from general provisions should be examined. With reference thereto, Hubmann is of the opinion that radio broadcasters are entitled to an absolute right to their own performance, though in special cases this may have to be restricted out of consideration for the interests involved. With regard to the difficulties occurring in practice, this writer regards the recording of sound broadcasts and the photographing of television broadcasts as admissible for one's own use, but not for commercial exploitation. The reproduction of broadcasts by loud speakers in public places (television is not referred to in this connection) is also considered to be admissible, but not the distribution of the broadcasts either by rebroadcasting or by wire. For the rest, the writer admits that legal regulation of all these matters is desirable, to clarify the situation.

\footnotetext{
${ }^{34}$ Id. at 4I, 42; ULMER, URHEBER- UND VERLAGSRECht 3 I6 (I95I); RUNGE, URHEBER- UND VERLAGsRECHT 342 (1948-1953).

${ }^{36}$ Reichsgericht (Supreme Court) Nov. 14, 1936, 553 Entscheidungen des Reichsgerichtes in Zivilsachen I.

${ }^{36}$ VoIgtLÄNDER-Elster-KLEJNE, op. cit. supra note 33 , at 42,44 ; ULMER, op. cit. supra note 34 , at 315, 319; A. Baum in IV Bulletin de DOCUMENTATION ET D'informatTon DE I'UNION EUROPÉNNE DE RADIODIFFUSION 511, 512 (1953).

${ }^{57} \mathrm{Cf}$. the case reported by ULMER, op. cit. supra note 34 , at $32 \mathrm{I}$.

${ }^{38}$ GRUR 3 I6 (I953); cf. also H. Dawid, in Pinner (Ed.), I Worrd Copyright 590-59r under (I4) and (15) (1953).
} 
In this connection it is worthy of notice that in Germany, as in the case of the United Kingdom, the intention to amend the existing legislation in this field has been announced. As far as Germany is concerned, a draft proposal for this amendment is available in the so-called "Academy Draft," which was drawn up by the Academy for German Law in $19399^{39}$ It is true that this draft proposal has not led directly to a bill, but it has continued to be discussed as a draft. ${ }^{40}$ This draft proposal includes under Chapter VI, "adjacent legal spheres," detailed provisions with reference to the protection of dramatic and artistic performers, image and sound recordings, and radio broadcasts.

Whoever has perused the above brief summary of the interests concerned and the outline of some of the legal arrangements, existing or proposed, for dealing with them, will be unable to avoid two conclusions. The first is that typical contemporary problems are involved and that it is desirable or even imperative that they should be studied and, if possible, regulated by statutory measures. The second is that in view of the great variety of the existing regulations and of the proposals made -and the fact that in other countries, such as France, Belgium, and the Netherlands there has been no arrangement at all to date-an effort to bring about international co-operation is necessary, to ensure that the greatest possible degree of uniformity of the statutory provisions and a minimum of protection can be obtained in countries where the interests concerned are approximately the same.

Some account has already been given of one such effort, which was undertaken under the auspices of the Permanent Committee of the Berne Convention, with the support of the International Labor Organization, and which has so far resulted in the Draft Convention, drawn up in Rome in $195 \mathrm{I}$ by a committee of experts. This effort to effect an international settlement of the problems concerned was by no means the first; as early as 1939 Dr. Ostertag, who had just resigned his function as Director of the Office of the.Berne Convention, published a draft convention, ${ }^{41}$ while in that same year at Samaden (Switzerland), a committee of experts appointed by the "Institut International pour l'Unification du Droit Prive" evolved two draft conventions to deal with the same material.42 These drafts, however, may be considered incorporated in the 195 draft drawn up in Rome, so that this is the only one that is of interest at this moment.

The most important provisions of the Rome draft are the following: ${ }^{13}$

${ }^{39}$ GRUR 242 (1939); text also reported by VoIGTLANDER-ELSTER-KIEINE, op. cif. supra note 33, at $\mathrm{x} 94$, and RuNGe, op. cit. supra note 34 , at 887 .

10 VOIGTLÄNDER-EISTER-KIEINE, OP. cit. stupra note 33 , at 1-2.

${ }^{41}$ Droit d'Auteur 1939, pp. 62, 71; this draft also covers the protection of letters, portraits, and ncws reports.

${ }^{42}$ Avant-projets de conventions connexes à la Convention de Berne pour la protection des oeuvres littéraires et artistiques, ed. Institut International pour l'Unification du droit privé, Rome, 1941. Cf. also Droit d'Auteur 1940, pp. 109, 121, 133; these comprise also separate drafts for conventions for the protection of news reports and for the award of a so-called "droit de suite" to the sales price of works of art.

${ }^{43}$ Droit d'Auteur 1951, p. I40. 
Art. 4 .

(I) Any performer who gives a recitation, presentation or performance of a work shall enjoy the right to authorize: (a) the recording of his recitation, presentation or performance with a view to the manufacture of phonographic records or similar instruments, intended to be sold to the public, and of cinematographic films intended to be exhibited in public halls; (b) the communication to the public of his recitation, presentation or performance by means of loud-speakers or any similar instruments transmitting signs, sounds or images; (c) the broadcasting of his recitation, presentation or performance when it is given for the purposes of a person or undertaking other than the body which proposes broadcast; (d) the recording, by any person, whatsoever, for broadcasting, of the performer's recitation, presentation or performance when given under the conditions specified in subparagraph (c) above.

(2) The right of authorization is not granted to the performer; (a) as against those who transmit by radiodiffusion or communicate to the public his recitation, presentation or performance by the means referred to in paragraph ( $x$ ) (a) and (d); (b) as against those who communicate to the public, whether over wires or not, or by whatever means, the broadcast of his recitation, presentation or performance.

(3) Reservations and conditions relating to the application of the rights mentioned in paragraph ( $\mathrm{r}$ ) (c) and (d) may be determined by legislation in each contracting country in so far as it may be concerned, but all such reservations and conditions shall apply exclusively in the country which prescribed them and shall in no case be prejudicial to the performer's right to obtain equitable remuneration fixed, failing prior agreement, by the competent authority.

(4) It shall be a matter for the legislation of the contracting countries to determine the conditions under which the broadcasting, recording, and communication to the public of short extracts from recitations, presentations or performances may be made for the purpose of reporting current events. It shall also be a matter for the said legislation to determine the regulations for ephemeral recordings fixing recitations, presentations or performances and made by a broadcasting organization by means of its own facilities and for its own emissions. The preservation of these recordings in official archives may, on the ground of their exceptional documentary character, be authorized by the said legislation.

Art. 6.

(I) The manufacturers of phonographic records and similar instruments shall enjoy: (a) the right to authorize the reproduction of their phonographic records and similar instruments by whatever means or process of recording; (b) the right to obtain an equitable remuneration from whomsoever uses their phonographic records or similar instruments for broadcasting or for any other method of communication to the public.

(2) The right to an equitable remuneration is not granted to manufacturers as against those who communicate to the public, whether over wires or not, or by whatever means, radio-emissions effected by means of their phonographic records or similar instruments.

(3) Phonographic records or similar instruments manufactured in a non-contracting country which, on the one hand, copy phonographic records or other instruments protected by this Convention and, on the other hand, are imported into a contracting country without permission from the manufacturer of the phonographic records or other instruments so reproduced, shall be liable to seizure.

(4) It shall be a matter for the legislation of the contracting countries to determine the conditions under which the broadcasting, the recording, and the communication to the public of short extracts from phonographic records or similar instruments may be made for the purpose of reporting current events. It shall also be a matter for the same 
legislation to determine the regulations for ephemeral recording fixing phonographic records or similar instruments and made by a broadcasting organization by means of its own facilities and for its own emissions. The preservation of these recordings in official archives may, on the ground of their exceptional documentary character, be authorized by the said legislation.

(5) It shall be a matter for the legislation of the contracting countries to designate the competent authority for fixing, in default of an amicable agreement, the amount of the equitable remuneration.

(6) It shall be reserved for the legislation of contracting countries to waive the application of paragraph (I) (b) in the case of communication to the public without a view to profit.

Art. 8.

(I) The broadcasting organization shall enjoy the right to authorize: (a) the reemission, whether over wires or not, of all or a part of their emission; (b) the recording or any other fixation of all or part of their emission or the re-emission by whatever means; (c) the communication to the public of all or part of their emission by means of any instrument transmitting images.

(2) It is reserved to the legislation of the contracting countries to protect the broadcasting organizations as against third parties who may communicate to the public all or part of their emission by means of loudspeakers or any other instrument transmitting sounds.

(3) Recordings of emissions or re-emissions protected by this Convention manufactured in a non-contracting country and imported into a contracting country without permission from the broadcasting organization from which they originate, shall be liable to seizure.

(4) It shall be a matter for the legislation of the contracting countries to determine under what conditions the re-emission, the recording, and the communication to the public of short extracts from emissions may be made for the purpose of reporting current events. It shall also be a matter for the same legislation to determine the regulations for ephemeral recordings fixing emissions or re-emissions and made by a broadcasting organization by means of its own facilities and for its own emissions. The preservation of these recordings in official archives may, on the ground of their exceptional documentary character, be authorized by the said legislation.

(5) It shall be reserved for the legislation of contracting countries to waive the application of paragraph $(\mathrm{I})(\mathrm{b})$ in the case of recordings and other fixations made for private use or without a view to profit.

Neither detailed criticism of these provisions nor a lengthy commentary thereon would be within the scope of this brief paper. A few remarks, however, would appear to be called for, the more so because with the above proposals the last word has certainly not been said in this matter; the consultations with reference thereto which have been outlined above have still to show their results.

Article 8, which appears to comprise a reasonable and well considered protection of broadcasts, seems to call least of all for criticism or commentary.

With reference to Article 6, however, the question immediately arises whether sufficient grounds have been adduced for the right to remuneration accorded to manufacturers of records in paragraph $I(b)$ of this Article, in case their records are used for broadcasting or for any other method of communication to the public (with 
the exception of paragraph 2). Various views are possible ${ }^{44}$ with reference thereto, with none of which I should like to side for the moment.

Another important feature of the Draft perhaps is that Article 4 is by no means clear-it is the result of a compromise which was very difficult to arrive at; moreover in conjunction with Article 6 it would hardly appear to be tenable in its entirety, because it is difficult to see why the dramatic and musical performers should receive less protection than the manufacturers of records.

That this is the situation according to the Draft is undeniable, since the right granted to the manufacturers in Article 6, paragraph r(b) in case of secondary use of their records (which right is restricted in paragraph 2), is explicitly denied to performing artists in Article 4, paragraph 2. It is possible that this is correct or unavoidable-about this point too I should not like to express an opinion at this juncture-but the incongruity as regards the right granted to the manufacturers of records seems bound to lead to difficulties. ${ }^{45}$

As stated above, a number of governments have been consulted with reference to the Draft in question. If only because their replies are not yet known, there is no point in going further into the details of the proposed arrangement. It may be regarded as probable, however, that the governments will see in this subject a challenge to (international) legislative work and that thus in some form or other, a Convention with reference to this material will appear in the near future.

It is very important what attitude the United States and the other countries of the Western Hemisphere (apart from Canada and Brazil, which as members of the Berne Convention are in a special position) will adopt with reference to this question. Will they throw their weight into the scale in time to ensure that the Convention to be concluded will also represent-or at any rate will not opposetheir views? Or will the unfortunate experience gained with the Berne Convention be repeated, i.e., that a number of countries conclude a convention and gradually elaborate it in such a way that it becomes entirely unacceptable to other countries, because their legal systems are too much at variance with it?

The posing of these last questions would in itself appear to be a sufficient ground for this paper.

" Cf. A. Baum in IV Bulletin De DOCUMENTATION ET D'inforMatTon DE L'UNION EUROpEENNE DE RAdiodifFusion 535 (1953).

${ }^{*} \mathrm{Cf}$. the amendment proposed by the representative of the French Government in the Consultative Committee of Employees and Intellectual Workers of the International Labor Organization, reported in Droit d'Auteur 1952, p. 36; according to this proposal it would be left to the national legislatures to ensure that the performing artists share in the profits accruing to the manufacturers of records from the secondary use of their records. 